\title{
Efektivitas Model Pembelajaran Kooperatif Tipe STAD dalam Mengembangkan Keterampilan Sosial
}

\section{Agnes Remi Rando1*, Agustina Pali²}

1,2 Pendidikan Guru Sekolah Dasar, FKIP - Universitas Flores, Flores, Indonesia

\section{A R T I C L E I N F O}

\section{Article history:}

Received March 09, 2021

Revised April 15, 2021

Accepted May 18, 2021

Available online July 25, 2021

\section{Kata Kunci:}

STAD, Pembelajaran IPS,

Keterampilan sosial

\section{Keywords:}

STAD, Social Studies

Learning, Social Skills

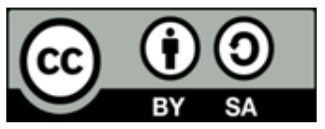

This is an open access article under the CC BY-SA license.

Copyright $(2021$ by Author. Published by Universitas Pendidikan Ganesha.

\begin{abstract}
A B S T R A K
Proses pembelajaran yang maish banyak focus kepada hasil belajar saja serta siswa masih terlihat kesulitan dalam berperilaku sesuai dengan tuntutan sosial, berinteraksi dan bekerjasama dengan orang lain, menjadi alasan penelitian yang bertujuan untuk mengkaji efektivitas model pembelajaran STAD terhadap kemampuan social siswa dilaksakan. Pendekatan penelitianyang digunakan adalah Penelitian Tindakan Kelas (PTK) model Kemmis Mc Taggart. Subjek penelitiannya berjumlah 22 siswa. Teknik pengumpulan data menggunakan observasi untuk mengetahui perkembangan keterampilan sosial peserta didik selama proses pembelajaran. Hasil penelitian menunjukan bahwa penerapan model pembelajaran kooperatif tipe Student Teams Achievement Division (STAD) secara efektif dapat mengembangakan keterampilan sosial peserta didik. Peningkatan keterampilan sosial peserta didik terlihat pada perubahan dari siklus I sebesar $20 \%$ dan siklus II menjadi $40 \%$. Dengan tingkat perubahan sebesar $20 \%$, dapat dikatakan bahwa pembelajaran IPS dengan model pembelajaran kooperatif tipe STAD efektif mengembangkan keterampilan sosial peserta didik.
\end{abstract}

\section{A B S T R A C T}

The learning process which still focuses a lot on learning outcomes and students still find it difficult to behave in accordance with social demands, interact and cooperate with others, is the reason for research that aims to examine the effectiveness of the STAD learning model on students' social abilities. The research approach used is Kemmis Mc Taggart's Classroom Action Research (CAR). The research subjects were 22 students. The data collection technique uses observation to determine the development of students' social skills during the learning process. The results showed that the application of the Student Teams Achievement Division (STAD) cooperative learning model could effectively develop students' social skills. The increase in students' social skills can be seen in the change from the first cycle of $20 \%$ and the second cycle to $40 \%$. With a change rate of $20 \%$, it can be said that social studies learning with the STAD type cooperative learning model is effective in developing students' social skills.

\section{PENDAHULUAN}

Pembelajaran adalah proses interaksi yang baik yang terjadi antara siswa dengan sumber belajar. Pembelajaran yang berkualitas akan berpengaruh terhadap hasil belajar siswa. pembelajaran berkulitas harus didukung oleh beberapa faktor salh satunya adalah keterampilan social yang harus dimiliki oleh siswa dalam proses pembelajar. Kemampuan sosial merupakan salah satu aspek penting bagi siswa dalam proses pembelajaran(Diahwati et al., 2016). Keterampilan sosial adalah kemampuan untuk berinteraksi dengan kondisi lingkungan sekitar sehingga dapat berperilaku sesuai dengan kondisi atau dengan kata lain beradaptasi dengan lingkungan sekitarnya(Alfianti et al., 2019). Seseorang yang memiliki keterampilan sosial tinggi dapat dengan mudah diterima oleh orang lain secara social (Diahwati et al., 2016). Pendapat lain menyatakan bahwa seaoarang siswa yang mempunyai kemampuan social yang rendah atau tidak memadai sering terlibat dalam bullying baik sebagai korban ataupun pelaku(Rupp et al., 2018). Siswa yang memepunyai keterampilan social napak dari kemapuan emapati dan ketegasan baik dalam berkomunikasi, kerjasama, tanggung jawab, kerelibatan dalam lingkungan sekolah, dan mampu mengendalikan diri yang mempengaruhi hunungan dengan teman sebayanya(Hu et al., 2021). Keterampilan social dapat diajarkan secara efektif untuk meningkat rendahnya keterampilan social siswa (Diperna et al., 2017; Elliott et al., 2019). jabaran tersebut memberikan 
gambaran bahwa kemampuan social sangat penting dalam proses pembelajaran untuk membentuk kepribadian siswa. Hal ini sejalan dengan hasil penelitian yang menyatakana bahwa keterampilan social sangat penting bagi siswa dalam membentuk pengalaman dan keterampilan social siswa dapat ditingkatkan dengan mengurangi tingkat setres yang dialami oleh siswa(Moeller \& Seehuus, 2019). Penelitian yang menyatakan bahwa keterampilan social akan memberikan pengaruh terhadap pembentukan sosiaemosional, capaian akademik dan kesehatan mental(Djambazova-Popordanoska, 2016; Jeon et al., 2020). Penelitian yang menyatakan bahwa keterampilan social dan kompetensi berdampak terhadap psikologi dan hubungan teman sebaya (Hamilton et al., 2016; Zayia et al., 2021).

Namun, proses pembelajaran yang dilakukan menggunakan metode dalam pembelajaran IPS sudah baik akan tetapi hasil yang diperoleh dari penerapan metode yang ada hanya sebatas pencapaian hasil atau nilai tanpa memperhatikan pengembangan keterampilan sosial peserta didik. Anak masih terlihat kesulitan dalam berperilaku sesuai dengan tuntutan sosial, berinteraksi dan bekerjasama dengan orang lain(Perdina et al., 2019). Jika kondisi ini dibiarkan akan berdampak terhadap keterampilan sosial dan kemampuan memecahkan masalah sosial yang rendah membuat siswa cenderung menjadi pelaku maupun korban bullying (Sri, 2014). Akan berdampak terhadap kemampuan siswa untuk memahami pesan yang disampaikan oleh peneliti saat pelajaran berlangsung masih perlu ditingkatkan karena masih terdapat beberapa siswa yang kurang memahami materi yang diberikan (Maharani, 2020). Serta keterlibatan sejumlah pelajar anak SD dalam sejumlah tindak kriminal ini dikhawatirkan menjadi pola perilaku yang berpotensi terus-menerus bertahan dan berulang akan menyebabkan kerusakan yang signifikan pada fungsi sosial, akademis, maupun masa depannya (Maksum \& Arifin, 2019). Siswa yang memiliki interaksi yang rendah akan berdampak negatif diantaranya kurangnya pengalaman, kurang berempati terhadap orang lain, merasa canggung berada dilingkungan pergaulan, mudah tersinggung serta berusaha menarik perhatian orang lain dengan cara menyombongkan diri (Zuhara, 2020). Jadi, dapat dikatakan bahawa saat ini kemampuan social siswa masih belum dikatakan baik ini nampak dari kurang sopannya siswa dalam proses pembelajaran banyak terjadi bullying di sekolah. Untuk mengatasi masalah tersebut maka diperlukan sebuah pembelajaran yang mampu mengembangkan kemampuan social siswa.

Peningkatan kualitas proses pembelajaran dapat dilakukan dengan berbagai strategi (Pratiwi et al., 2017), strategi yang dilakukan adalah dengan menggunakan berbagai macam metode, teknik, strategi, media, dan model pembelajaran yang variatif sesuai dengan tujuan dan kebutuhan(Dewi et al., 2019; Kusumayanti et al., 2017), serta melakukan perbaikan dalam proses pembelajaran yang sesaui dengan kondisi siswa (Puryadi et al., 2018). Berkaiatan dengan penggunaan model pembelajaran yang digunakan guru harus memilih model yang mampu merangsang minat siswa dalam belajar secara aktif dan memahami materi yang sedang dibelajarakan(Permana et al., 2017). Salah satu model pembelajaran yang digunakan dalam proses pembelajaran adalah Model pembelajara kooperatif tipe STAD. Pembelajaran kooperatif dicirikan oleh struktur tugas, tujuan, dan penghargaan yang kooperatif. Model pembelajaran kolaboratif tidak hanya membantu siswa memahami konsep, tetapi juga membantu siswa mengembangkan keterampilan kolaboratif, berpikir kritis, dan mengembangkan hasil belajar siswa(Sirajuddin, 2018). Pembelajaran kooperatif menciptakan pembelajaran yang demokratis, dimana pembelajaran ini memberikan kesempatan untuk mengembangkan dan memberdayakan potensi siswa secara maksimal (Nugroho \& Shodikin, 2018). Salah satu model kooperatif adalah STAD.

STAD terdiri dari lima komponen utama-presentasi kelas, tim, kuis, skor peningkatan individu, dan pengakuan tim (Rumapea, 2018; Sunarti \& Rachman, 2018). Pembelajaran dengan model STAD dapat mendukung siswa untuk berkreasi dalam melaksanakan pembelajaran dan mengembangkan kemampuan saling membantu dengan teman sebaya dalam proses pembelajaran (Munawar, 2019). Serta pembelajaran STAD memberikan kesempatan pada peserta didik untuk berinteraksi lebih intensif dengan teman sebayanya, sehingga lebih mudah dalam menyelesaikan permasalahan (Ahyar et al., 2017; Hadinata et al., 2017). Selian itu pembelajaran STAD mengarah kepada proses kemunikasi secara dua arah (Istiqamah, 2019). Jadi, Model STAD dapat memberikan pengaruh yang positif terhadap pembetukan socialemosional, kerja sama dan dapat meningkatkan pemahaman siswa terhadap materi. Pernyataan ini sesuai dengan hasil penelitian yang menyatakan bahwa penerapan pembelajaran STAD berbantuan media komik efektif ditinjau dari tingkat ketuntasan belajar siswa, aktivitas siswa, aktivitas guru, dan respon siswa (Nugroho \& Shodikin, 2018). Penelitian yang menyatakan bahwa Model pebelajaran STAD dapat meningkatkan kerjasama diantara siswa (Sutinah, 2015). Penelitian yang menyatakan bahwa penerapan model pembelajaran Student Teams Achievement Divisions (STAD) berpengaruh terhadap keaktifan dan hasil belajar geografi siswa (Nikmah et al., 2016). Penelitian yang menyatakan bahwa terdapat perbedaan hasil belajar IPA dan self-efficacy siswa yang menggunakan model pembelajaran kooperatif STAD berbantuan mind map dan model pembelajaran langsung (Sari et al., 2018). Penelitian yang menyatakan bahwa model pembelajaran kooperatif tipe Student Teams Achievement Division (STAD) berbantuan media video pembelajaran tentang Perjuangan Kemerdekaan Indonesia berpengaruh terhadap hasil belajar (Navisha et al., 2017). Penelitian yang menyatakan bahwa tidak terdapat perbedaan hasil belajar siswa yang diajar dengan metode STAD antara siswa yang mempunyai kemampuan potensi akademik tinggi dan rendah (Primartadi, 2013). Penelitian yang menyatakan penerapan 
pembelajaran inkuiri terbimbing yang diperkaya dengan unsur-unsur STAD dapat meningkatkan hasil belajar peserta didik (Ahyar et al., 2017). Penelitian yang menyatakan bahwa model pembelajaran kooperatif tipe STAD berpengaruh positif dan signifikan terhadap keterampilan sosial siswa (Budiastana, 2015). Penelitian yang menyatakan bahwa menunjukkan terdapat perbedaan yang signifikan antara siswa yang mengikuti model pembelajaran STAD dan TSTS. Perbedaan signifikan dari penerapan dua model dapat dilihat pada rerata posttest keterampilan sosial dari kedua kelas (Lestari \& Setyaningtyas, 2020). Jabaran-jabaran itu memberikan alasan mengapa penelitian yang bertujuan untuk mengkaji efektivitas model pembelajaran STAD terhadap kemampuan social siswa dilaksakan. Penelitian ini berbeda dengan penelitian yang sudah ada sebelumnya hal ini karena penelitian yang sudah ada lebih focus kepada hasil belajar siswa namuan penelitian ini akan lebih focus kepada kemampuan social siswa.

\section{METODE}

Penelitian ini adalah penelitian tindakan kelas (PTK) yang mengangkat masalah-masalah aktual yang dihadapi oleh guru dilapangan (Wibawa, 2004:3). Dalam rancangan penelitian ini peneliti menggunakan prosedur penelitian dari Model Kemmis \& Mc Taggrt. Desain Model Kemmis \& Mc Taggrt lebih memfokuskan pada aspek individual dalam penelitian tindakan. Alur fikir dan alur kerja yang ditawarkan Kemmis \& Mc Taggrt ada empat yaitu: perencanaan, tindakan, dan observasi, refleksi. Sebelum melakukan tindakan terlebih dahulu dilakukan perencanaan agar pelaksanaan pembelajaran kooperatif tipe STAD dapat berjalan dengan baik.. Persiapan yang dilakaukan sebelum tindakan adalah menyiapkan perangkat pembelaaran berupa RPP, lembar kerja siswa (LKS), serta lembar observasi untuk menilai kegiatan peserta didik. Adapun data yang diambil adalah data aktivitas peserta didik yang diobservasi pada saat pembelajaran berlangsung. Kegiatan observasi diarahkan pada aktivitas yang berkenaan dengan keterampilan sosial. Pelaksanaan tindakan dilakukan oleh peneliti sendiri sedangkan guru mata pelajaran IPS bertindak sebagai pengamat untuk menilai aktivitas peserta didikTujuan dari penelitian ini adalah untuk mengetahui keefektivan pembelajaran kooperatif tipe STAD dalam mengembangkan keterampilan sosial siswa di SDI Ende 14. Subjek penelitian ini adalah peserta didik kelas IV SDI Ende 14 berjumlah 22 orang. Teknik pengumpulan data menggunakan wawancara untuk mengetahuai kondisi awal sebelum melakuakan tindakan, observasi dilakukan untuk mengetahui tingkat pengembangan keterampilan sosial peserta didik. Data dianalisis menggunakan teknik analisis kualitatif. Penelitian ini data yang diperoleh dari penilaian observasi aktivitas keterampilan sosial peserta didik selama proses pembelajaran menggunakan model kooperatif tipe STAD.

\section{HASIL DAN PEMBAHASAN}

\section{Hasil}

Hasil pelaksanaan tindakan I dan II diperoleh hasil bahwa proses pembelajaran yang dilakukan di kelas IV sangat baik. Hal ini dibuktikan dengan penilaian aktivitas keterampilan sosial peserta didik melalui observasi kelas selama kegiatan pembelajaran berlangsung. Hasil yang diperoleh adalah adanya peningkatan aktivitas keteramplan sosial peserta didik selama proses pembelajaran berlangsung. Nampak pada siklus I jumlah aktivitas yang muncul adalah 28 dengan rata-rata sebesar 2,8 dan persentase sebesar 20\%. Dan siklus II terjadi peningkatan jumlah aktivitas sebesar 47 dengan rata-rata 4,7 dan persentase yang diperoleh sebesar $40 \%$. Peningkatan aktivitas peserta didik dari siklus I dan siklus II menunjukan bahwa model pembelajaran kooperatif tipe STAD sangat efektif digunakan dalam pembelajaran IPS untuk mengembangkan keterampilan sosial peserta didik di SDI Ende 14. Pembelajaran IPS dengan menggunakan model kooperatif tipe STAD dapat mengembangkan keterampilan sosial siswa di SDI Ende 14, karna materi pembelajaran IPS lebih fokus membahas tentang bagaiaman menyikapi fenomena sosial yang terjadi. Hal ini juga didukung dengan penggunaan model pembelajaran STAD akan memberikan kesempatan kepada siswa untuk belajar secara bersama-sama, hal ini akan sangat berdampak terhadap hubungan yang terjalin antara siswa. Model pembelajaran STAD memberikan kesempatan berbagi harapan belajar sesama siswa hal ini berarti model ini memberikan kesempatan kepada siswa untuk berinteraksi satu sama lain untuk saling mempengaruhi secara positif. Hubungan yang baik dengan teman sebaya sangat efektif karena siswa akan tetap tertarik dalam proses belajar. Pembelajaran teman sebaya akan mendorong siswa untuk berperan aktif dalam pembelajaran (Oh, 2019) dan meningkatkan belajar mandiri serta siswa akan memiliki pengalaman yang merupakan umpan balik dari temannya (Gabriele et al., 2016). Teman sebaya membantu, membimbing dan mendukung rekan-rekan mereka sehingga mereka dapat belajar melalui interaksi dan kolaborasi (Andersen \& Watkins, 2018). Pembelajaran teman sebaya mengurangi kecemasan dan stres, sementara bimbingan, dukungan, dan umpan balik teman sebaya memungkinkan siswa mengembangkan kepercayaan diri (Han et al., 2015; Stone et al., 2013). Berdasarkan uraian tersebut, pembelajaran harus memungkinkan siswa untuk berbagi harapan belajar mereka untuk menghasilkan pembelajaran yang bermanfaat sesuai dengan kondisi saat ini. Pembelajaran seperti ini sesaui dengan pembelajaran STAD. Pembelajaran dengan model STAD dapat mendukung siswa untuk 
berkreasi dalam melaksanakan pembelajaran dan mengembangkan kemampuan saling membantu dengan teman sebaya dalam proses pembelajaran(Munawar, 2019). Serta pembelajaran STAD memberikan kesempatan pada peserta didik untuk berinteraksi lebih intensif dengan teman sebayanya, sehingga lebih mudah dalam menyelesaikan permasalahan(Ahyar et al., 2017; Hadinata et al., 2017). Selian itu pembelajaran STAD mengarah kepada proses kemunikasi secara dua arah (Istiqamah, 2019). Jadi, Model STAD dapat memberikan pengaruh yang Positif terhadap pembetukan socialemosional, kerja sama dan dapat meningkatkan pemahaman siswa terhadap materi. Pernyataan ini sesuai dengan hasil penelitian yang menyatakan bahwa penerapan pembelajaran STAD berbantuan media komik efektif ditinjau dari tingkat ketuntasan belajar siswa, aktivitas siswa, aktivitas guru, dan respon siswa (Nugroho \& Shodikin, 2018). Jadi, keefektivan pembelajaran tipe STAD memberikan dampak yang sangat baik terhadap sikap dan perilaku siswa sebagai proses pembentukan keterampilan sosial.

Kemampuan sosial merupakan salah satu aspek penting bagi siswa dalam proses pembelajaran (Diahwati et al., 2016). Keterampilan sosial adalah kemampuan untuk berinteraksi dengan kondisi lingkungan sekitar sehingga dapat berperilaku sesuai dengan kondisi atau dengan kata lain beradaptasi dengan lingkungan sekitarnya(Alfianti et al., 2019). Seseorang yang memiliki keterampilan sosial tinggi dapat dengan mudah diterima oleh orang lain secara social (Diahwati et al., 2016). Pendapat lain menyatakan bahwa seaoarang siswa yang mempunyai kemampuan social yang rendah atau tidak memadai sering terlibat dalam bullying baik sebagai korban ataupun pelaku (Rupp et al., 2018). Siswa yang memepunyai keterampilan social napak dari kemapuan emapati dan ketegasan baik dalam berkomunikasi, kerjasama, tanggung jawab, kerelibatan dalam lingkungan sekolah, dan mampu mengendalikan diri yang mempengaruhi hunungan dengan teman sebayanya(Hu et al., 2021). Keterampilan social dapat diajarkan secara efektif untuk meningkat rendahnya keterampilan social siswa (Diperna et al., 2017; Elliott et al., 2019). Salah satu model pembelajaran yang digunakan adalah STAD. Model STAD dapat memberikan pengaruh yang Positif terhadap pembetukan socialemosional, kerja sama dan dapat meningkatkan pemahaman siswa terhadap materi.

Hasil penelitian ini sejalan dengan hasil penelitian yang menyatakan bahwa penerapan pembelajaran STAD berbantuan media komik efektif ditinjau dari tingkat ketuntasan belajar siswa, aktivitas siswa, aktivitas guru, dan respon siswa (Nugroho \& Shodikin, 2018). Penelitian yang menyatakan bahwa Model pebelajaran STAD dapat meningkatkan kerjasama diantara siswa (Sutinah, 2015). Penelitian yang menyatakan bahwa penerapan model pembelajaran Student Teams Achievement Divisions (STAD) berpengaruh terhadap keaktifan dan hasil belajar geografi siswa (Nikmah et al., 2016). Penelitian yang menyatakan bahwa terdapat perbedaan hasil belajar IPA dan self-efficacy siswa yang menggunakan model pembelajaran kooperatif STAD berbantuan mind map dan model pembelajaran langsung (Sari et al., 2018). Penelitian yang menyatakan bahwa model pembelajaran kooperatif tipe Student Teams Achievement Division (STAD) berbantuan media video pembelajaran tentang Perjuangan Kemerdekaan Indonesia berpengaruh terhadap hasil belajar (Navisha et al., 2017). Penelitian yang menyatakan bahwa tidak terdapat perbedaan hasil belajar siswa yang diajar dengan metode STAD antara siswa yang mempunyai kemampuan potensi akademik tinggi dan rendah (Primartadi, 2013). Dan penelitian yang menyatakan penerapan pembelajaran inkuiri terbimbing yang diperkaya dengan unsur-unsur STAD dapat meningkatkan hasil belajar peserta didik (Ahyar et al., 2017). Penelitian yang menyatakan bahwa model pembelajaran kooperatif tipe STAD berpengaruh positif dan signifikan terhadap keterampilan sosial siswa (Budiastana, 2015). Penelitian yang menyatakan bahwa menunjukkan terdapat perbedaan yang signifikan antara siswa yang mengikuti model pembelajaran STAD dan TSTS. Perbedaan signifikan dari penerapan dua model dapat dilihat pada rerata posttest keterampilan sosial dari kedua kelas (Lestari \& Setyaningtyas, 2020). Jadi berdasarkan jabaran hasil penelitian dan hasil penelitian sebelumnya dapat diakatakan bahwa model pembelajaran STAD efektif untuk meningkatkan kemampuan social siswa hal ini karena pembelajaran dengan Model STAD dapat merangsang siswa untuk berinteraksi dengan baik dan berkerja sama

\section{SIMPULAN}

Model pembelajaran STAD efektif untuk meningkatkan kemampuan social siswa hal ini etrlihat dari peningktakan kerja sama siswa dan adanya interaksi antar siswa. direkomendasikan kepada pendidik untuk menggunkan model STAD karena sudah terbukti dari hasil penelitian dapat meningkatakan hasil belajar dan kemampuan social siswa.

\section{DAFTAR PUSTAKA}

Ahyar, L. M., Ibnu, S., \& Affandy, D. (2017). Penerapan Stad Dalam Pembelajaran Inkuiri Terbimbing Dan Pengaruhnya Terhadap Hasil Belajar Peserta Didik. J-PEK (Jurnal Pembelajaran Kimia), 2(1), 21-30. https://doi.org/10.17977/um026v2i12017p021.

Alfianti, R. A., Suprapta, B., \& Andayani, E. S. (2019). Model Pembelajaran Interaktif dan Keterampilan Sosial 
terhadap Hasil Belajar Kognitif Siswa pada Pembelajaran Sejarah di SMA. Jurnal Pendidikan: Teori, Penelitian, Dan Pengembangan, 4(7), 938. https://doi.org/10.17977/jptpp.v4i7.12636.

Andersen, T., \& Watkins, K. (2018). The value of peer mentorship as an educational strategy in nursing. Journal of Nursing Education, 57(4), 217-224. https://doi.org/10.3928/01484834-20180322-05.

Budiastana, P. (2015). Pengaruh Penerapan Model Pembelajaran Kooperatif Tipe STAD Terhadap Kemampuan Kognisi dan Keterampilan Sosial Pada Siswa Sekolah Menengah Pertama. Ekuitas: Jurnal Pendidikan Ekonomi, 1(1). https://doi.org/10.23887/ekuitas.v3i1.12782.

Dewi, A. C., Hapidin, \& Akbar, Z. (2019). Pengaruh Model Pembelajaran dan Kemampuan Berpikir Kritis terhadap Pemahaman Sains Fisik. Jurnal Obsesi: Jurnal Pendidikan Anak Usia Dini, 3(1), 18. https://doi.org/10.31004/obsesi.v3i1.136.

Diahwati, R., Hariyono, H., \& Hanurawan, F. (2016). Keterampilan Sosial Siswa Berkebutuhan Khusus Di Sekolah Dasar Inklusi. Jurnal Pendidikan: Teori , Penelitian Dan Pengembangan, 1(8), 1612-1620. https://doi.org/10.17977/jp.v1i8.6682.

Diperna, J. C., Lei, P., Cheng, W., Hart, S. C., \& Bellinger, J. (2017). A Cluster Randomized Trial of the Social Skills Improvement System-Classwide Intervention Program (SSIS-CIP) in First Grade James. Journal of Educational Psychology, 110(1), 1-16. https://doi.org/10.1037/edu0000191.

Djambazova-Popordanoska, S. (2016). Implications of emotion regulation on young children's emotional wellbeing and educational achievement. Educational Review, 68(4), 497-515. https://doi.org/10.1080/00131911.2016.1144559.

Elliott, S. N., Hwang, Y. S., \& Wang, J. (2019). Teachers' ratings of social skills and problem behaviors as concurrent predictors of students' bullying behavior. Journal of Applied Developmental Psychology, 60(November 2018), 119-126. https://doi.org/10.1016/j.appdev.2018.12.005.

Gabriele, K. M., Holthaus, R. M., \& Boulet, J. R. (2016). Usefulness of Video-Assisted Peer Mentor Feedback in Undergraduate Nursing Education. Clinical Simulation in Nursing, 12(8), 337-345. https://doi.org/10.1016/j.ecns.2016.03.004.

Hadinata, L. W., Utaya, S., \& Setyosari, P. (2017). Pengaruh Pembelajaran Student Team Achievement Division Dan Diskusi Terhadap Hasil Belajar Ipa Kelas Iv Sd. Jurnal Pendidikan: Teori, Penelitian, Dan Pengembangan, 2(7), 979-985. https://doi.org/10.17977/jptpp.v2i7.9693.

Hamilton, J. L., Potter, C. M., Olino, T. M., Abramson, L. Y., Heimberg, R. G., \& Alloy, L. B. (2016). The Temporal Sequence of Social Anxiety and Depressive Symptoms Following Interpersonal Stressors During Adolescence. Journal of Abnormal Child Psychology, 44(3), 495-509. https://doi.org/10.1007/s10802015-0049-0.

Han, J.-S., Baek, H. C., \& Jeong, A.-S. (2015). The Effects of Psychiatric Nursing Simulation on Anxiety and Selfconfidence about Clinical Placement of Nursing Students. Journal of the Korea Academia-Industrial Cooperation Society, 16(11), 7812-7819. https://doi.org/10.5762/kais.2015.16.11.7812.

Hu, B. Y., Li, Y., Wang, C., Wu, H., \& Vitiello, G. (2021). Preschool teachers' self-efficacy, classroom process quality, and children's social skills: A multilevel mediation analysis. Early Childhood Research Quarterly, 55, 242251. https://doi.org/10.1016/j.ecresq.2020.12.001.

Istiqamah. (2019). Pembelajaran Menulis Karangan Deskripsi Dengan Model Kooperatif Tipe STAD Terhadap Siswa Kelas X MAN 3 Aceh Utara Jurnal. Jurnal Ilmiah DIDAKTIKA, 19(2), 216-235. https://doi.org/10.22373/jid.v19i2.5034.

Jeon, H. J., M. McCartney, C., Richard, V., \& Johnson, S. J. (2020). Associations between parent-teacher and teacherchild relationships and children's socioemotional functioning. Early Child Development and Care, $0(0), 1-$ 15. https://doi.org/10.1080/03004430.2020.1711747.

Kusumayanti, N. P. C., Asri, I. G. A. A. S., \& Putra, D. K. N. S. (2017). Pengaruh Model Pembelajaran Problem Based Learning Berbantuan Audio Visual Terhadap Kompetensi Pengetahuan IPS Siswa Kelas V. Mimbar PGSD, 5(2), 1-10. https://doi.org/10.23887/jisd.v2i2.15494.

Lestari, D., \& Setyaningtyas, E. W. (2020). Perbedaan Pengaruh Model Pembelajaran STAD dengan TSTS terhadap Keterampilan Sosial Muatan IPS. Didaktika Tauhidi: Jurnal Pendidikan Guru Sekolah Dasar, 7(1), 55. https://doi.org/10.30997/dt.v7i1.2659.

Maharani, A. (2020). Meningkatkan Pemahaman Bahasa Indonesia Lisan, Kreativitas, dan Keterampilan Sosial Anak Melalui Cerita Bergambar. Jurnal Pendidikan, 5(2), 1-7. https://doi.org/10.26740/jp.v5n2.p1-7.

Maksum, K., \& Arifin, A. S. (2019). Pola Pendekatan Penanganan Gangguan Perilaku ( conduct disorder ) pada Pelajar SD : Sebuah Upaya Mengurangi Perilaku Kekerasan Pelajar di Yogyakarta. MODELING: Jurnal Program Studi PGMI Volume, 6(2), 259-277. https://doi.org/10.36835/modeling.v6i2.513.

Moeller, R. W., \& Seehuus, M. (2019). Loneliness as a mediator for college students' social skills and experiences of depression and anxiety. Journal of Adolescence, 73(March), 1-13. https://doi.org/10.1016/j.adolescence.2019.03.006.

Munawar, H. (2019). The application of STAD-Cooperative Learning Model: Efforts to increase motivation and Learning Outcomes of students in Class 5 SD N 07 Ledok Salatiga in Mathematics subjecth in Folding 
Symmetry and Rotating Symmetry topics. MUDARRISA: Jurnal Kajian Pendidikan Islam, 11(2), 114-135. https://doi.org/10.18326/mdr.v11i2.114-135.

Navisha, R. I., Tastra, I. D. K., \& Dibia, I. K. (2017). Pengaruh Model Stad Berbantuan Media Video Pembelajaran Terhadap Hasil Belajar Ips Siswa Sd Kelas V. MIMBAR PGSD Undiksha, 5(2). https://doi.org/10.23887/jjpgsd.v5i2.10935.

Nikmah, E. H., Fatchan, A., \& Wirahayu, Y. A. (2016). Model Pembelajaran Student Teams Achievement Divisions (STAD), Keaktifan dan Hasil Belajar Siswa. Jurnal Pendidikan Geografi, 3(3), 1-17. http://jurnalonline.um.ac.id/data/artikel/artikelE91D7FB9C21685AA36E47BE7A44B0CC7.pdf.

Nugroho, S., \& Shodikin, A. (2018). Keefektifan Pembelajaran Student Teams Achievement Division ( Stad ) Berbantuan Komik ( Learning Effectiveness of Student Teams Achievement. Jurnal Matematika Dan Pendidikan Matematika, 3(1), 22-32. https://doi.org/10.26594/jmpm.v3i1.1067.

Oh, E. (2019). Research on the effective of peer instruction and students' involvement. Asia-Pacific of Multimedia Services Convergent with Art Humanities, and Sociology, 9, 199-208. https://doi.org/https://doi.org/10.35873/ajmahs.

Perdina, S., Safrina, R., \& Sumadi, T. (2019). Peningkatan Kemampuan Sosial melalui Bermain Kartu Estafet pada Anak Usia Dini. Jurnal Obsesi: Jurnal Pendidikan Anak Usia Dini, 3(2), 440. https://doi.org/10.31004/obsesi.v3i2.222.

Permana, I. P. A. I., Dantes, N., \& Parmiti, D. P. (2017). Pengaruh Model Pembelajaran Kuantum Terhadap Hasil Belajar IPS Siswa Kelas V. MIMBAR PGSD Undiksha, 5(2). https://doi.org/10.23887/jjpgsd.v5i2.10910.

Pratiwi, P. H., Nur, H., \& Martiana, A. (2017). Pengembangan Modul Mata Kuliah Penilaian Pembelajaran Sosiologi Berorientasi Hots. Jurnal Cakrawala Pendidikan, 201-209. https://doi.org/10.21831/cp.v36i2.13123.

Primartadi, A. (2013). Pengaruh Metode Student Teams-Achievement Division (STAD) dan Mroblem Based Learning Terhadap Hasil Belajar Ditinjau dari Potensi Akademik Siswa SMK Otomotif. Jurnal Pendidikan Vokasi, 2(2), 143-153. https://doi.org/10.21831/jpv.v2i2.1024.

Puryadi, P., Rahayu, S., \& Sutrio, S. (2018). Pengaruh Model Pembelajaran Direct Instruction Berbantuan Bahan Ajar Berbasis Kontekstual Terhadap Hasil Belajar IPA Terapan Siswa Kelas X SMKN 4 Mataram Tahun Ajaran 2015/2016. Jurnal Pendidikan Fisika Dan Teknologi, 4(1), 23. https://doi.org/10.29303/jpft.v4i1.329.

Rumapea, R. (2018). Pengaruh Model Pembelajaran Kooperatif Tipe Stad dan Pemberian Soal Open Ended Terhadap Kemampuan Pemecahan Masalah Siswa Ditinjau dari Kemampuan Awal Matematika. Pendidikan Matematika, 12(1), 1-14. https://ejournal.unsri.ac.id/index.php/jpm/article/view/4551/pdf.

Rupp, S., Elliott, S. N., \& Gresham, F. M. (2018). Assessing elementary students' bullying and related social behaviors: Cross-informant consistency across school and home environments. Children and Youth Services Review, 93, 458-466. https://doi.org/10.1016/j.childyouth.2018.08.028.

Sari, N. P. I. K., Arnyana, I. B. P., \& Mardana, I. B. P. (2018). Pengaruh Model Pembelajaran Kooperatif Stad Berbantuan Mind Map Terhadap Hasil Belajar Ipa Dan Self Efficacy Siswa Kelas Viii Smp. Jurnal Imiah Pendidikan Dan Pembelajaran, 2(2), 229-236. https://doi.org/10.23887/jipp.v2i2.15607.

Sirajuddin. (2018). Pengaruh Model Pembelajaran Kooperatif Dan Minat Belajar Siswa Terhadap Hasil Belajar Sejarah. Jurnal Ekonomi Efektif, 1(1), 64-83. https://doi.org/10.32493/JEE.v1i1.1982.

Sri, W. (2014). Efektivitas Program Resolusi Konflik Untuk Meningkatkan Kemampuan Pemecahan Masalah Sosial Siswa Yang Terlibat Perilaku Bullying. Jurnal Psikologi UIN Sultan Syarif Kasim Riau, 10(Juni), 5358. https://doi.org/10.24014/jp.v10i1.1179.

Stone, R., Cooper, S., \& Cant, R. (2013). The Value of Peer Learning in Undergraduate Nursing Education: A Systematic Review. ISRN Nursing, 2013(i), 1-10. https://doi.org/10.1155/2013/930901.

Sunarti, S., \& Rachman, D. (2018). The Effectiveness of Flip Classroom with Student Teams-Achievement Divisions (STAD) Method to Teach Reading Viewed from Students' English Learning Interest. Script Journal: Journal of Linguistic and English Teaching, 3(2), 183. https://doi.org/10.24903/sj.v3i2.246.

Sutinah. (2015). Model Pembelajaran Kooperatif Tipe Students Team Achievement Devision (STAD). Jurnal Penelitian Pendidikan, 1-12. https://ojs.unm.ac.id/tomalebbi/article/download/2848.

Zayia, D., Parris, L., McDaniel, B., Braswell, G., \& Zimmerman, C. (2021). Social learning in the digital age: Associations between technoference, mother-child attachment, and child social skills. Journal of School Psychology, 87(June 2020), 64-81. https://doi.org/10.1016/j.jsp.2021.06.002.

Zuhara, E. (2020). Efektivitas Konseling Kelompok Dengan Teknik Modeling Untuk Meningkatkan Interaksi Sosial Siswa. Jurnal Edukasi: Jurnal Bimbingan Konseling, 6(1), 41. https://doi.org/10.22373/je.v6i1.8208. 